\section{WE LIVE TO SERVE}

According to a survey of over 1,000 consumers, dentists provide far better customer service than those in other professions.

In the study, by customer service training experts Results International, 47\% of people said they think dentists have a good customer service attitude, compared to just 27\% who voted for doctors and 30\% for waiters. People are more than twice as likely to receive good customer service from dentists as they are from bar staff.

Groups more likely to be noted for poor customer service include police, general shop assistants, post office staff and council workers. www.resultsinternational.com

\section{HONOURS, AWARDS, APPOINTMENTS}

\section{IADR Executive Team}

Richard Johnson and Barry Quinn have been elected onto the Executive Team of the IADR Education Research Group in the roles of Secretary and Councillor respectively. Mr Johnson is Head of Nursing, Dental Hygiene and Therapy and Allied Health Professionals at Guy's and St Thomas' NHS Foundation Trust and Honorary Senior Clinical Teacher at King's College London Dental Institute. Dr Quinn is Director at St Thomas' Dental Centre and Learning and Teaching Coordinator at King's College London Dental Institute.

\section{Senior Clinical Hatton}

Dr Gerry McKenna, a lecturer in prosthodontics and oral rehabilitation at University College Cork, has been awarded the IADR Senior Clinical Hatton Award for his work entitled Tooth replacement strategies for older patients: $a$ randomised controlled trial.

\section{Ben Fund Honours}

The BDA's Benevolent Fund honoured Dr Mavis Phipps at its Annual General Meeting in June and commemorated the late Air Vice-Marshal lan Mclntyre. Dr Phipps was elected VicePresident in recognition of her 23 years of service to the fund. An engraved gavel was presented in memory of lan Mclntyre.

\section{New SDPC Chair}

Dr Robert Donald, a dentist in the Highlands, has been elected Chair of the BDA's Scottish Dental Practice Committee (SDPC), succeeding Dr Robert Kinloch.

\section{Honorary Fellowship}

Professor Shahram Tabibi has been granted an Honorary Fellowship from the University of Central Lancashire (UCLan) where he was the founder and the Head of the School of the Institute for Postgraduate Dental Education from 2006-2010.

\section{National Teaching Fellowship}

Sara Holmes MBE, the Head of the University of Portsmouth's Dental Academy, has received a National Teaching Fellowship from the Higher Education Academy. Fellowship award winners receive $£ 10,000$ which may be used for their professional development in teaching and learning or aspects of pedagogy.

\title{
JAWS DIDN'T HAVE TOOTHACHE
}

Shark teeth have fluoride built in, according to a study published in the Journal of Structural Biology. ${ }^{1}$

Researchers at the University of Duisburg-Essen in Germany studied the teeth of two different shark species. Whereas the teeth of humans and other mammals contain hydroxyapatite, an inorganic constituent found in bone, shark teeth contain the mineral fluoroapatite (fluorinated calcium phosphate).

In addition to the unique structure of their teeth, which enables them to tear or cut the flesh of their prey, sharks also have more than one row of teeth and are able to replace their teeth several times in their lifetime.

1. Enax J, Prymak O, Raabe D, Epple M. Structure, composition, and mechanical properties of shark teeth. J Struct Biol 2012; 178: 290-299.

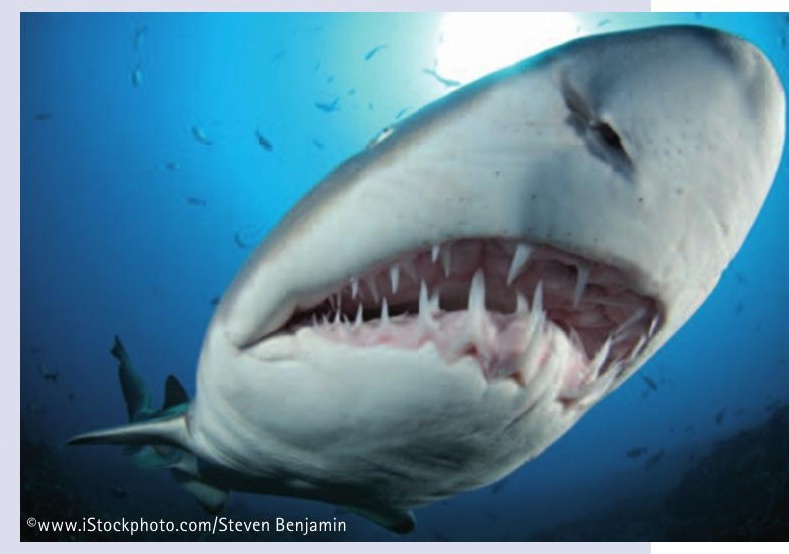

\section{SECRET SERVICE DENTIST LEAVES LEGACY}

The Faculty of Dental Surgery at the Royal College of Surgeons of England is delighted to have received a legacy of around $£ 10,000$ from a dentist who worked with the Special Operations Executive (SOE) during World War II.

Beryl Murray Davies was a retired dental surgeon who qualified in 1933, reports the Dean's Newsletter, who had a flourishing Harley Street practice from the 1940 s until the early 1990 s. During the War she is known to have worked with the SOE, replacing the 'English' dental work of operatives about to be dropped into occupied territories with dental work more appropriate to the nationality that they were proposing to adopt for their mission.

Fillings were replaced to match 'European-style' dentistry in case the individual was killed or captured. This work was often carried out at night and alone by $\mathrm{Dr}$ Davies with no assistant, and was veiled in deepest secrecy.

'We are led to believe that [Dr Davies] was understandably cross that [her work] was never recognised after the war', says the Dean's Newsletter.

The legacy was presented to the Faculty by Dr Davies' goddaughter, Michelle Berridale-Johnson, who wrote of her godmother: 'she was entirely devoted to her profession so I am sure that she would appreciate being involved in anything which would either enhance it or enable a budding dental surgeon to reach their full potential.'

The Faculty would like to help bring recognition to the work of Beryl Murray Davies; if anyone knows anything of this lady or the dental work of the SOE, please email jdonald@rcseng.ac.uk.

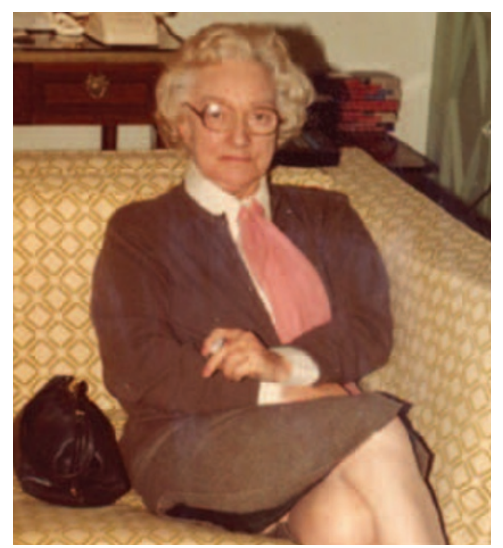

